\title{
A Case Study of EFL Teachers' Perceptions and Practices in Written Corrective Feedback
}

\author{
Hussam Rajab (Corresponding author) \\ English Language Institute, King Abdulaziz University, Jeddah, Saudi Arabia \\ E-mail: hmrajab@kau.edu.sa \\ Khalid Khan \\ School of Forensic and Investigative Sciences, University of Central Lancashire, Preston, PR1 2HE, Lancashire, UK \\ Tariq Elyas \\ English Language Institute, King Abdulaziz University, Jeddah, Saudi Arabia
}

Received: 16-06-2015

Published: 01-01-2016
Accepted: 18-09-2015

doi:10.7575/aiac.ijalel.v.5n.1p.119
Advance Access Published: October 2015

URL: http://dx.doi.org/10.7575/aiac.ijalel.v.5n.1p.119

\begin{abstract}
Based on a mixed-method approach, this interpretive exploratory case study aimed to identify English as Foreign Language (EFL) teachers' perceptions and practices in Written Corrective Feedback (WCF) in the Saudi context. The study analysed quantitative data gathered from an anonymous custom designed 15-question online survey and qualitative data from an open-ended question (at the end of the online survey) and semi-structured interviews. Participants were one hundred and eighty-four English as a Foreign Language (EFL) teachers $(n=184)$ who responded to the online survey (113 females and 71 males) and 7 participants who responded to the semi-structured interview (5 males and 2 females). The study findings indicated no significant differences between male and female teachers in considering "time" as the main factor in following a particular strategy for written corrective feedback (93\%). The results from the semi-structured interviews highlighted the need for further research in written corrective feedback in the Saudi context to address serious issues related to the teachers' work-load. Some recommendations were identified for further research in written corrective feedback.
\end{abstract}

Keywords: Saudi, Mixed methods, Survey, Written corrective feedback

\section{Introduction}

Written corrective feedback (WCF) is considered one of the most important tasks that writing teachers can provide for their students (Ferris 2006). Interest in WCF research has grown in the last two decades. However, in the Saudi context, research in the corrective feedback field has been hitherto neglected and scarce. Teachers' concerns and opinions are of paramount importance and usefulness in a successful learning environment. Nevertheless, many teachers view research as unrelated to their work environment and often perceive that others' research findings are inapplicable to their own particular classroom settings (Mackey \& Gass 2005). As Lacorte and Krastel (2002) have observed, "teachers must take a critical look at their own actions within the classroom and consider possible issues within their systems of practical knowledge, beliefs, and attitudes that could be improved" (p. 914). Bailey (2001) concurs, noting that "By reading or hearing accounts of other people's research, [teachers] can get new ideas for teaching and for their investigations, as well as becoming better connected with their profession at large" (p. 496). Furthermore, Wallace (1991) argues that reflective teaching provides an opportunity for the development of professional competence by combining two prime sources of knowledge in practice: received and experiential knowledge.

\subsection{Study significance}

This study investigates the importance of EFL teachers' (male and female) perception and cognition in WCF in the Saudi context. Its significance lies in the insights it offers into the perceptions of teachers in a country (Saudi Arabia) witnessing major changes in education in general and in the teaching of EFL in particular. To ensure a smooth transition from previous practice, the heads of EFL departments as well as educational decision makers, in Saudi Arabia need to be aware of the challenges facing EFL teachers. One of these major challenges is the time constraints faced by EFL teachers in Saudi Arabia, which have compromised the quality of certain areas of EFL teaching such as WCF.

\subsection{The problem}

English is becoming the language of instruction in the majority of tertiary institutions in Saudi Arabia. Several of these institutions focus on the 'quantity' of their curriculum rather than 'quality' in the sense that their emphasis is on covering as many units or chapters of the EFL textbooks as possible. As a consequence, EFL teachers experience great pressure in their attempts to meet the scheduling deadlines set by their institutions' schedule deadlines, very often at the 
expense of the quality of their teaching, particularly with regard to the teaching of writing and the lack of an appropriate WCF. In the worst-case scenario, many dedicated EFL teachers end up as composition slaves, which is a term coined by Maxine Hairston (1986) in her article 'On not being a composition slave', which describes the toil and drudgery that many EFL teachers face when giving WCF. Coupled with the low levels of English proficiency reported in almost all grade levels in Saudi Arabia (Al-Shammari 2005), this weakness leads many students to underachieve in English and prevents them from receiving the benefits that might be gained from WCF. EFL teachers in Saudi Arabia face a perpetual professional dilemma: they want to provide sound WCF on their students' writing assignments but are unable to do so because of they are short of time.

\subsection{Study purpose}

The main aim of this study is to examine and investigate EFL teachers' perceptions of WCF practices in the Saudi context. From an analytical perspective, by understanding EFL teachers' WCF practices and perceptions, one can clearly identify the problematic areas in teaching and learning EFL. Although this research has been conducted by a male researcher and is therefore likely to reflect some degree of gender bias, it has been designed to provide female EFL teachers with an equal opportunity to share their opinions and concerns regarding provision of WCF in Saudi Arabia. These findings should create a clearer picture of the issues faced by EFL teachers in Saudi Arabia and concerns about WCF. Squire and Bliss (2004) argue that “decades of research on the connection between teachers' theoretical beliefs and their practices yield a common theme: all teachers bring to the classroom some level of beliefs that influence their critical decision making" (p. 756).

\subsection{Research questions}

The present research study aims to answer the following four main questions: (1) What is the perception of WCF by EFL (writing) teachers at tertiary institutions in Saudi Arabia? (2) If teachers were given autonomy in their work contexts, what is (in the eyes of the EFL teachers in Saudi Arabia) the most effective pedagogical approach to WCF? (3) Do teachers have different WCF strategies/approaches for different settings? (e.g., using an unfocused [comprehensive] WCF approach if the class size is small and using focused [selective] WCF approach if the class size is large.) (4) Is there any significant difference in WCF practices and beliefs between male and female EFL teachers in Saudi Arabia? These four research questions were divided into a 14-item Likert scale itemized online questionnaire as well as an open-ended question at the end of the questionnaire. Research question 4 was formulated into a null hypothesis where Ho was that there were no significant difference whereas the alternative $\mathrm{H}_{\mathrm{A}}$ was that significant difference existed.

\section{Literature review}

WCF in its simplest form is defined as the "type of information, which is provided for the learners about his or her performance of a learning task, usually with the aim of improving this performance" (Ur 1996:242). Since Truscott (1996) published his paper, "The case against grammar correction in L2 writing classes", in which he rejected the idea of any benefits of WCF, the debate of whether WCF is beneficial or not has polarized researchers into an apparent dichotomy of for versus against WCF. Truscott (1996) concluded that WCF (mainly grammar corrections) should not have a place in writing courses and disciplines and should be scrapped because it is both ineffective and harmful. He based his conclusions on a research study where he compared an English as a second language (ESL) group that received extensive correction and another identical group that only received content-oriented comments. The results of his study showed that the second group (content group) attained significantly higher scores than the first group (correction group). He additionally backed his findings up with the analysis of studies performed by Semke (1984), Kepner (1991), and Sheppard (1992). In a way, Truscott and advocates of his theory exposed the idea that research evidence of the effectiveness of WCF in helping learners improve their L2 proficiency level is insufficient and inconclusive. However, opposition to this theory was not idle and strong rebuttals came from Ferris (1999; 2000; 2004), who opposed Truscott's (1996) ideas and provided evidence for the use of WCF. Ferris (1999) asserted that Truscott's (1996) arguments were premature and weak given the rapidly growing research evidence that suggests that effective error correction can and does help L2 student writers if the feedback is selective, prioritized, and unambiguous. Chandler (2003) further confirms Ferris's (1999) findings by stating that Truscott's reliance on the findings of previous studies was somehow not supported by the data collected in those studies and, furthermore, Truscott did not always consider the sound statistical calculations in these studies, which were mainly 'statistically significant'. This finding was further supported by several studies (Hong 2004; Montgomery \& Baker 2007; Bitchener and Knoch 2008; Lee 2008). Hong (2004) noted that Truscott's premature views were based on only cross-sectional studies, which did not provide comprehensive conclusions on the long-term development of grammar accuracy in L2 learners. Montgomery and Baker (2007) as well as Bitchener, Young and Cameron (2005) indicated that learners believe that WCF does not only improve their L2 writing (vyatkina 2011), but also their L2 grammar. In his 2-month study investigating the efficacy of WCF of 75 low-intermediate ESL learners in New Zealand, Bitchener (2008) found that WCF improved the accuracy of those 75 ESL learners in two functional uses of the English indefinite "a" and definite "the" articles. In addition, Lee's (2008) study investigated the reactions of EFL learners in two secondary classrooms to Hong Kong teachers' feedback, which showed that students desired more WCF from their teachers.

Looking at WCF from a different perspective, it is not necessarily the case that this camp or that camp is better or that the argument is to "to grade or not to grade" because the foundation for both camps is the same. Truscott and Ferris have implicitly agreed that more research is needed because their existing data was insufficient to answer the question of whether WCF can be effective in improving the accuracy of L2 learners' writing. As Ferris (1999) noted, "If nothing 
else, reading Truscott's essay and reviewing the primary sources he cites, has highlighted for me the urgent need for new research efforts which use a variety of paradigms to examine a range of questions that arise around this important topic" (p. 2). Conversely, some researchers do not necessarily adopt or support either Truscott's or Ferris's camps, but merely illustrate a point. The latter is evident in Coffin's (2003) book, where she makes it abundantly clear that WCF is both difficult and time-consuming because each student's work (needing feedback) has its own problems, which demand an individual response. It is generally perceived that for most L2 writing teachers, the preferred and most widespread strategy of feedback is WCF (Ferris 1997; 2007). Second-language (L2) learners/writers especially need WCF because they often have issues not only with their L1 first/native language interference, but also an incomplete understanding of their L2 (Cox et al. 2010; Ferris 2002; Hyland \& Hyland 2001).

\subsection{Teachers' WCF strategies}

There are a range of different WCF styles and overlapping terminologies. However, traditionally there are two main types of WCF strategies that L2 writing teachers provide to their learners: direct and indirect WCF. Direct WCF is the act of indicating error types such as 'preposition' and 'tense' where the L2 writing teacher provides the correct form directly next to (or near) the error committed. However, indirect WCF merely indicates where the error or incorrect form occurred by underlining, highlighting, or circling it without providing the student with the correct form (Lee 2008; Young et al. 2005). Ferris and Roberts (2001) assert that indirect feedback is more effective because it "helps students to make progress in accuracy over time more than direct feedback does [...] or at least equally as well" (p. 164). Two subcategories stem from indirect WCF: coded and uncoded WCF. Some researchers view coded WCF as similar to direct WCF where the former is said to occur when the L2 writing teachers indicate the error with a code (e.g., 'CS' refers to comma splice), whereas indirect WCF is similar to uncoded WCF in that the errors in the latter are merely highlighted by the teacher (e.g., with a highlighter or underlining with a pen) without providing a specific identification of the type of error (Wayne 2013).

Focused WCF selects specific errors to correct and ignore other errors. Highly focused WCF will focus on a single error type (e.g., errors in the use of the past simple tense). Conversely, a less-focused WCF will be applied to more than one error type, but will still restrict correction to a limited number of pre-selected types (e.g., simple past tense, articles, or prepositions) (Wayne 2013). In contrast, unfocused WCF refers to what might be considered a routine practice in writing instruction (but may not exactly correspond to what L2 writing researchers advocate) where teachers mark and correct all (or at least a range of) the errors in learners' written work. This type of WCF is seen as 'extensive' because it treats a variety of errors. The following diagram (Figure 1) illustrates the different strategies used by L2 writing teachers in WCF.

\section{Written Corrective Feedback}

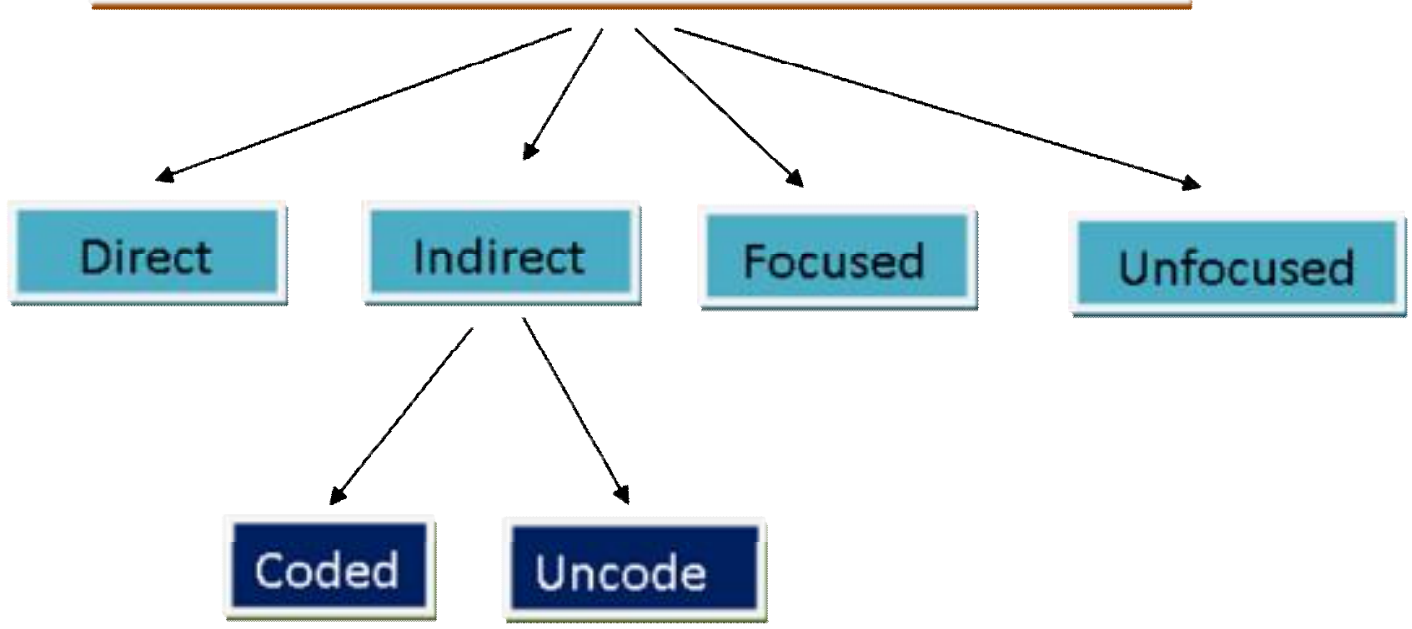

Figure 1. Illustration of different WCF types/strategies used by L2 writing teachers

Because direct feedback appears to be a straightforward type and easier to follow than indirect WCF, it is quite popular amongst students (Amrhein \& Nassaji 2010). Ferris (2002) looked at the effects of different WCF strategies on both text revisions and newly submitted pieces of writing and reported that $88 \%$ of correct revisions were attributed to direct WCF compared with $77 \%$ of indirect WCF. However, L2 writing teachers prefer indirect WCF because it is a much politer and less-intimidating form of feedback than direct WCF (Thonus 2002). Moreover, it is more effective for the students than direct WCF in giving students the opportunity to correct their own errors which, in the long run, may contribute to less dependency on the teacher (Ferris 2007) and in addition, improving proficiency through student centeredness and autonomy (Ferris 2003). In two similar studies that are almost two decades apart, Lalande (1984) and Chandler (2003) examined the accuracy in two groups of ESL/L2 students' writing following direct WCF to the first group and indirect coded WCF to the second, and concluded that the students' accuracy in the second group (indirect 
coded WCF) by the end of the semester was higher than the first group (direct WCF). However, there is a vital point to consider when it comes to indirect coded WCF. This factor is teaching the specific codes used by the teacher in the indirect coded WCF and making them familiar to the student (Lee 2008). This is because students find it more difficult to understand and familiarize themselves with different types of errors committed with the corresponding codes than direct WCF (Holtgraves 1999).

\section{Methodology}

The design of this research study is a 'fixed' mixed-methods design (Creswell \& Clark 2010) using data collection and analysis in parallel form of both pillars of research: quantitative and qualitative research designs (Kemper, Stringfield and Teddlie 2003). Mixed-methods design can be seen as a procedure intended for collecting, analysing, and 'mixing' both quantitative and qualitative data at some stage of the research process within a single study to understand a research problem more completely (Creswell 2002).

In this exploratory investigation, fixed mixed-method design was chosen to give better triangulation, greater validity, and credibility to the quantitative survey findings. Additionally, many EFL teachers in Saudi Arabia feel freer to communicate their opinions in a professional setting such as a faculty meeting, a conference, or in this case, an interview. The survey was designed to comprise 15 items (14 close-ended questions and one open-ended section for additional information). The survey was followed by 10 semi-structured interviews with male and female EFL teachers in Saudi Arabia.

\subsection{Study population}

The targeted population of this study consisted of 184 EFL teachers in Saudi Arabia (113 females and 71 males). Those participants were randomly selected (simple random sampling) from 20 tertiary institutions throughout Saudi Arabia. Those teachers were chosen from a long list of EFL teachers at different universities/colleges in Saudi Arabia. The semi-structured interviews were conducted with seven EFL teachers ( 5 male and 2 female). No two teachers were chosen from the same college/university for the sake of randomizing and obtaining as much data from various EFL teachers in Saudi Arabia as possible. E-mails were sent to 200 EFL teachers at tertiary institutions in Saudi Arabia containing a link to the survey hosted by www.surveymonkey.com. A convenient sample selection of intended participants (20) who were sent the e-mails with the link to the survey, were further asked if they wished to participate in a short semi-structured interview (approximately 15-20 minutes). The response rate for the survey was $92 \%(n=184)$ and that for the semi-structured interviews was $35 \%(n=7)$. Participation in this research study was voluntary.

\subsection{Teachers' questionnaire}

The teachers' questionnaire (Appendix A) was intended to gather quantitative data anonymously from the EFL teachers in Saudi Arabia regarding their perception of WCF. The first part of the questionnaire sought to gather demographic information (e.g., gender, highest qualification, course taught, etc). The second part was devised to collect answers to the research questions from the EFL teachers. The latter part (questions 7-14) was to closed-ended questions such the dichotomous yes/no answers as well as ticking the relevant choice. The third part of the questionnaire was a single open-ended question to give EFL teachers a chance to add comments and statements relevant to the survey at hand. This latter part was optional, where the participants were at liberty to add any comments they wished to make.

\subsection{Semi-structured interviews}

In this study, where semi-structured interviews were performed in the second part, a list of questions relating to areas in WCF was prepared by the researcher and was intentionally chosen because of its informality and openness (Appendix B). In this research study, semi-structured interviews were conducted because of the level of freedom and ease that EFL teachers feel when interviewed in addition to the fact that EFL teachers in Saudi Arabia have in general, an extremely heavy schedule, it is the only setting to get them to agree to participate in an in-depth research study. Because of the social constraints that exist in Saudi Arabia, face-to-face interviews with female EFL teachers were not possible, except for two interviews during an international conference where the researcher managed to conduct face-to-face interviews with female EFL teachers after the conference. Table 1 illustrates the semi-structured interviews performed by the researcher.

Table 1. Participant interview details

\begin{tabular}{|c|c|c|c|c|}
\hline Participant & Gender & Nationality & Interview & Date \\
\hline EFL Teacher (University) & Male & Australian & Face - to - Face & March 2013 \\
\hline EFL Teacher (University) & Female & British & Face - to - Face & March 2013 \\
\hline EFL Teacher (College) & Male & British & Face - to - Face & March 2013 \\
\hline EFL Teacher (University) & Male & South African & Face - to - Face & March 2013 \\
\hline EFL Teacher (University) & Male & Canadian & Face - to - Face & March 2013 \\
\hline EFL Teacher (University) & Male & American & Face - to - Face & March 2013 \\
\hline EFL Teacher (University) & Female & British & Face - to - Face & April 2013 \\
\hline
\end{tabular}


The survey was aimed to appeal to as many EFL teachers in Saudi Arabia as possible with its brief and short answers as well as being completely anonymous. A randomly selected list of 7 EFL teachers ( 5 female and 2 male; Table 1$)$ from 7 different tertiary Saudi institutions were sent e-mails inviting them to participate in a face-to-face interview as a follow up to the survey where it was made known to the participants that absolute anonymity would be guaranteed. The semistructured interviews were conducted to gather the most detailed information possible. The interviews were not always confined to a closed list of the same questions (Appendix B); each interview allowed as much freedom as possible to each interviewee to express his/her own views and thoughts within the general framework of WCF topics. Reference was made to the survey findings at each interview and the participants were given the opportunity to comment and express their opinions. A consent form (Appendix C) was sent to each participant by e-mail. All seven participants who took part in the interviews expressed their wishes to remain completely anonymous (i.e., no reference to their names or place of work). All interviews were conducted individually and the bulk content of the each interview lasted about 1015 minutes. Because this research study was about EFL teachers' perceptions of WCF in the Saudi context, both survey and interviews were conducted only in English.

\section{Analysis}

The findings of each of the two parts of the questionnaire and the semi-structured interviews will be discussed as follows: (1) close-ended questions 1-14; (2) open-ended question, 15; and (3) semi-structured interviews. Data collected from the close-ended questions were analysed using Microsoft Excel ${ }^{\circledR}$ and IBM SPSS (Ver.15) ${ }^{\circledR}$. Data collected from interviews were audio-taped and transcribed verbatim and were analysed by thematic analysis using QSR International NVIVO ${ }^{\circledR}$ software. Word frequencies and tag clouds were created to view the potential themes in the interviews.

\subsection{Close-ended questions}

The survey questions 1-14 were grouped into three sections where each section shared common a common theme or area of focus. The first section of the survey included four questions, questions 1, 2, 3, and 4. Those questions related to consent of participation in the survey, participant's gender, highest academic qualification attained by the participant and the courses that each EFL teacher was teaching at the time of taking the survey, respectively. The results are shown in Table 2.

Table 2. Gender, highest level of education completed and course currently taught.

\begin{tabular}{|c|c|c|c|c|}
\hline $\begin{array}{l}\text { Question } \\
\text { Number }\end{array}$ & Question & Response & $n$ & $\%$ \\
\hline \multirow[t]{2}{*}{2.} & \multirow[t]{2}{*}{ What is your gender? } & Male & 71 & $39 \%$ \\
\hline & & Female & 113 & $61 \%$ \\
\hline \multirow[t]{6}{*}{3.} & \multirow{6}{*}{$\begin{array}{l}\text { What is the highest level of education you have } \\
\text { completed? }\end{array}$} & Types of qualifications & & \\
\hline & & Diploma & 4 & $2 \%$ \\
\hline & & Bachelor's degree & 33 & $18 \%$ \\
\hline & & Post Grad Cert. of Ed. & 21 & $11 \%$ \\
\hline & & Master's degree & 107 & $58 \%$ \\
\hline & & Doctoral degree & 19 & $10 \%$ \\
\hline \multirow[t]{6}{*}{4.} & \multirow[t]{6}{*}{ What course do you teach at your institution? } & Type of course & & \\
\hline & & 101 & 11 & $6 \%$ \\
\hline & & 102 & 18 & $10 \%$ \\
\hline & & PYP $1^{\text {st }}$ Semester & 26 & $14 \%$ \\
\hline & & PYP $2^{\text {nd }}$ Semester & 44 & $24 \%$ \\
\hline & & PYP Other & 85 & $46 \%$ \\
\hline
\end{tabular}

It is generally assumed that the higher the level of courses taught, the more weight is given to writing in comparison with the other L2 skills. It is clear that the preparatory year program (PYP) other (taught courses) choice, which may include IELTS, TOEFL, EAP, ESP, and so on, is the largest group because several courses are introduced every semester in Saudi Arabia in addition to the main PYP courses.

The second section of the survey which formed the main bulk of the survey, looked at the practical aspects of WCF. Question 5 concerned class sizes, which play a big factor in WCF because the bigger the class, the more demanding the WCF process. This is more often deemed time-consuming and exhausting because of the relationship between WCF difficulty and the class size. As shown in Table 3, the majority of class sizes were between 15-20 and 21-25 students per class.

Question 6 was crucial in learning the number of contact hours each EFL teacher had because the more hours the teacher has, the more work-load, and therefore participants may adopt different WCF strategies. This is indirectly linked to research question 3 in this study, which concerns different WCF strategies that the EFL teacher may apply. Table 3 illustrates details of contact hours taught by all participants by gender. Although the majority of teachers had four contact hours per day ( $44 \%$ for both male and female teachers), it is quite alarming to discover that $10 \%$ of teachers had 6 contact hours and more. 
Question 8 concerned the number of written assignments given per week. It is clear that the majority of EFL teachers at tertiary institutions in Saudi Arabia — more than half of the participants in this survey - give a written assignment once a week.

Question 10 concerned the percentage of students' submitted written assignments requiring WCF from the teacher. The majority of participants answered with $80-100 \%$. However, it is evident that nearly half the participants do not give $80-$ $100 \%$ WCF on the students' submitted written assignments. Further analysis revealed that $73 \%$ of those teachers who give only $0-20 \%$ and $20-40 \%$ WCF on returned assignments have class sizes over 20 . Furthermore, $80 \%$ of teachers having class sizes over 30 gave $0-20 \%$ WCF.

Question 11 asked participants about the number of hours allocated for WCF per week. The results reveal that the majority of participants (43\% male and 62\% female) allocate between 1-2 hours and 2-3 hours for WCF. Using SPSS ${ }^{\circ}$ software, an independent t-test was conducted to determine if a difference existed between the mean times (minutes) spent on WCF by female and male teachers. There was no statistically significant difference between the mean times (minutes) spent on WCF by females $(n=113, M=166.99, S D=73.14)$ and males $(n=71, M=156.76, S D=68.4), t(184)=$ $0.947, p=0.35$. The effect size, eta squared $\eta^{2}=0.005$ was small. Therefore the Null hypothesis is accepted. i.e. that the same amount of time on average is spent on WCF by males and females. The latter, together with the answers to question 9 of the survey, are both directly related to research question 4 of this study concerning differences in WCF between male and female EFL teachers in Saudi Arabia.

Question 12 concerned the preferred type of WCF given by the participants. In response, $42 \%$ of the participants (male and female) prefer the indirect coded WCF followed by focused (selective) WCF and unfocused (comprehensive) WCF. The least practiced type was the indirect noncoded WCF at only $9 \%$.

Table 3. Average class sizes taught, daily contact hours, number of assignments set for students, percentage of submitted assignments that receive WCF, average hours allocated for CF and type of WCF provided.

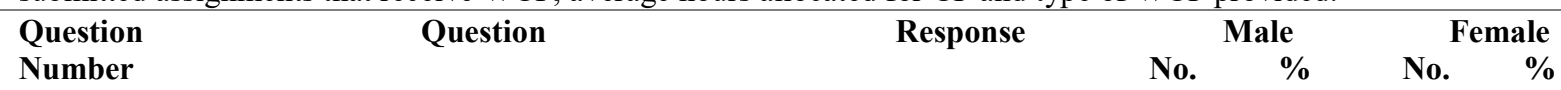

On average, how many students do you teach per class?

\begin{tabular}{llccc} 
No. of students & & & & \\
\hline $0-10$ & 4 & $(2 \%)$ & 5 & $(3 \%)$ \\
\hline $15-20$ & 41 & $22 \%)$ & 45 & $(24 \%)$ \\
\hline $21-25$ & 15 & $(8 \%)$ & 27 & $(13 \%)$ \\
\hline $25-30$ & 8 & $(4 \%)$ & 17 & $(9 \%)$ \\
\hline$>30$ & 3 & $(2 \%)$ & 19 & $10 \%)$ \\
\hline
\end{tabular}

6.

How many contact hours do you have per

No. of contact hours day?

\begin{tabular}{llccc}
\hline 2 & 13 & $(7 \%)$ & 23 & $(13 \%)$ \\
\hline 3 & 7 & $(4 \%)$ & 16 & $(9 \%)$ \\
\hline 4 & 41 & $(22 \%)$ & 44 & $(24 \%)$ \\
\hline 5 & 5 & $(3 \%)$ & 17 & $(9 \%)$ \\
\hline 6 & 3 & $(2 \%)$ & 8 & $(4 \%)$ \\
\hline 6 & 2 & $(1 \%)$ & 5 & $(3 \%)$ \\
\hline
\end{tabular}

8. $\quad$ On average, how many written assignments do you require your students to complete a week?

No. of times a week

\begin{tabular}{llrll}
\hline 1 & 32 & $(17 \%)$ & 67 & $(36 \%)$ \\
\hline 2 & 25 & $(14 \%)$ & 16 & $(9 \%)$ \\
\hline 3 & 9 & $(5 \%)$ & 27 & $(15 \%)$ \\
\hline$>3$ & 5 & $(3 \%)$ & 3 & $(2 \%)$
\end{tabular}

10.

What is the percentage of the students'

$\%$ of students submitted written assignments that receive written corrective feedback?

\begin{tabular}{llcll}
\hline $0-20 \%$ & 6 & $(3 \%)$ & 9 & $(5 \%)$ \\
\hline $20-40 \%$ & 5 & $(3 \%)$ & 11 & $(6 \%)$ \\
\hline $40-60 \%$ & 5 & $(3 \%)$ & 15 & $(8 \%)$ \\
\hline $60-80 \%$ & 10 & $(5 \%)$ & 29 & $(16 \%)$ \\
\hline $80-100 \%$ & 45 & $(24 \%)$ & 49 & $(27 \%)$ \\
No. of hours & & & & \\
\hline $1-2$ hours & 27 & $(15 \%)$ & 38 & $(21 \%)$ \\
\hline $2-3$ hours & 21 & $(11 \%)$ & 32 & $(17 \%)$ \\
\hline $3-4$ hours & 15 & $(8 \%)$ & 25 & $(14 \%)$ \\
\hline$>4$ hours & 8 & $(4 \%)$ & 18 & $(10 \%)$
\end{tabular}

12.

What type of written corrective feedback do you usually provide?

\begin{tabular}{llrll} 
Types of feedback & & & & \\
\hline Focused & 14 & $(8 \%)$ & 32 & $(17 \%)$ \\
\hline Indirect coded & 25 & $(14 \%)$ & 51 & $(28 \%)$ \\
\hline Indirect non-coded & 9 & $(5 \%)$ & 7 & $(4 \%)$ \\
\hline Unfocused & 23 & $(13 \%)$ & 23 & $(13 \%)$ \\
\hline
\end{tabular}


The third section of survey related to the EFL teachers' general perception and practices at their current place of employment with regards to WCF. Question 7 looked at whether institutions in Saudi Arabia designate specific lessons or lectures for writing. It is quite evident from the results that the majority of teachers answered 'no' to the question with a total of 60 and $40 \%$ answering with 'yes'. This is indirectly related to research question 2 of this study concerning the way EFL teachers choose their lessons if they are given autonomy.

Question 9 concerned whether the teacher provided his/her students with WCF on their written assignments. Interestingly, nearly all of the participants answered 'yes' (98\%) except two female and one male teacher who answered 'no'.

Question 13 concerned whether the participants provided their students with a follow-up session after the students were given WCF on their assignments that they previously submitted. The majority of participants $(65 \%)$ answered 'yes' to giving a follow-up session to the students in comparison with 'no' (35\%).

The last close-ended question of the questionnaire (question 14) concerned 'time' as a crucial factor in participants' decision to adopt a particular WCF style. The results indicated that an overwhelming majority of $96 \%$ answered 'yes' compared with 4\% who answered with 'no' (Table 4).

Table 4. Whether special classes are designated at institutions, whether WCF is provided, whether follow up sessions are provided after WCF and whether time is consider a crucial factor in providing WCF.

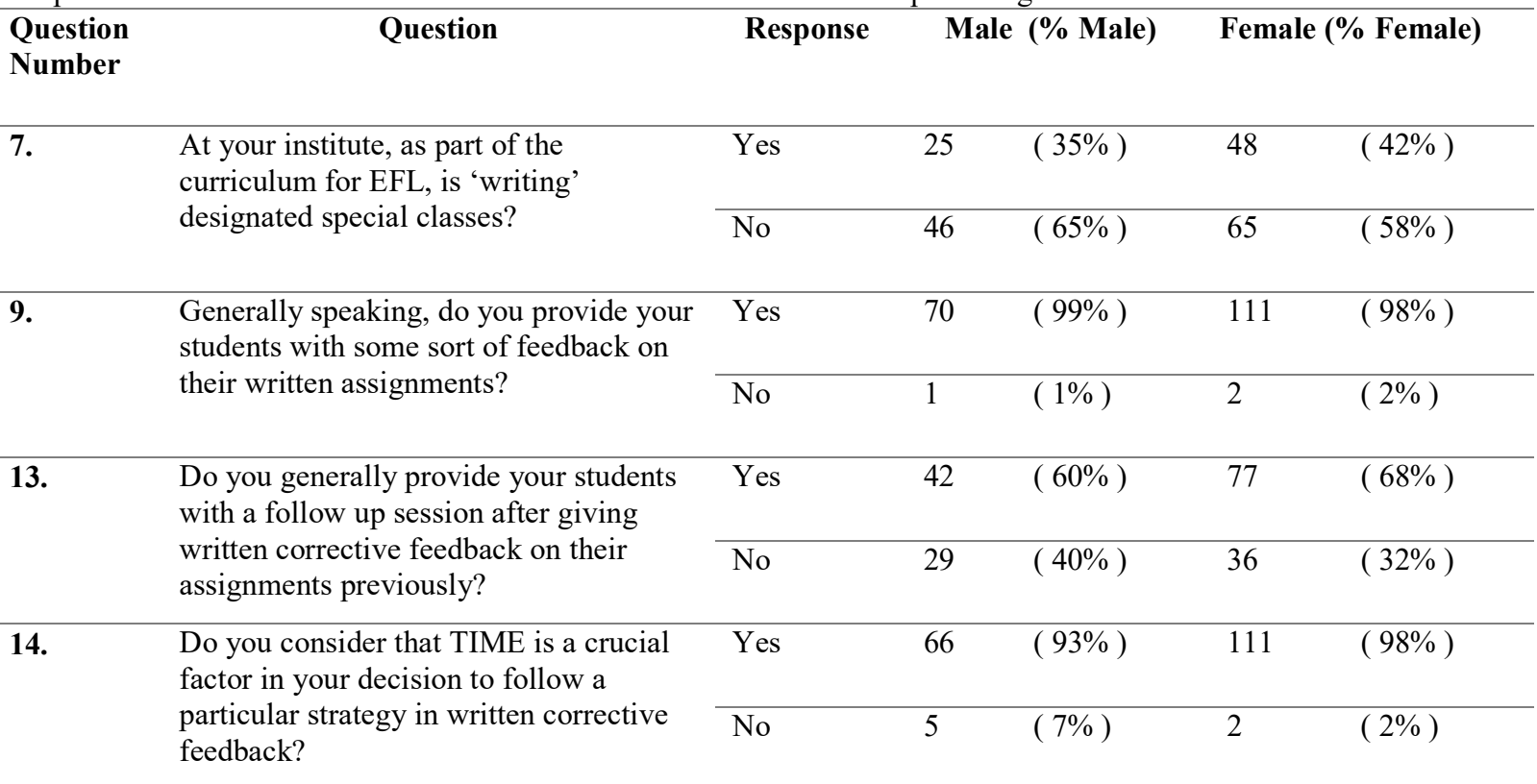

\subsection{Open-ended question (question 15 of the questionnaire)}

Question 15 was an open-ended question, which was intended to give the participants a chance to give any comments they felt relevant to WCF. It was also intended for the participants to elaborate further on a particular topic or even give any suggestions or criticism regarding the research study. According to Creswell (2007), utilising open-ended questioning analysis is well suited for research studies where the intended goal is to seek a range of possible experiences among a similar group of participants, as it was in this study.

There were 81 comments in total, which mainly focussed on two main areas: teachers and errors. This was obtained using the text-analysis software, $N$ Vivo ${ }^{\circledR}$ where initially, the data was queried into word frequency distributions and tag clouds. The analysis gave a thematic word frequency as well as a percentage of occurrences in the participants' comments (Figure 2).

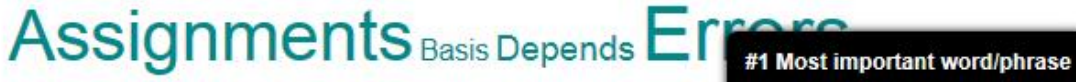 Follow Good Luck Kind Main Goal Practice Problems Required Remurte Skill Teachers Teaching Think wish $_{\text {Th }}$}

Figure 2. Text analysis and thematic representation of word frequencies in question 15 using NVivo ${ }$ software. 
The word 'teachers' appeared in nearly $37 \%$ of the participants' replies/texts followed by 'errors', which appeared in nearly $24 \%$ of the participants replies/texts.

\subsection{Semi-structured interviews}

Data analysis began immediately after each interview was conducted. Patterns for generalization within each interview and between the other interviews were listed (Erickson 1986). Certain perceived themes were categorized under larger themes such as time, work-load, and class size. The interviews centred on questions related to the best WCF strategy followed and why it was the best: what are the current issues relating to students' written assignments? How does WCF assist in reducing errors in the short term and the overall second-language acquisition (SLA) in the long term? All participants who volunteered in the interviews expressed their professional views about certain issues related to WCF where class sizes, types of written assignments, lack of unified policy on WCF at many tertiary institutions in Saudi Arabia, overloaded work, and institutions' strict guidelines to meet curriculum deadlines that might be counterproductive in some situations where writing revisions and follow-up sessions are extremely difficult to provide to the students.

\section{Discussion and conclusion}

In this present study, the main focus was to learn the teacher's side of the story. This study confirms previous studies' findings concerning 'time' being a crucial factor in WCF (Ur 1996; Truscott 1999; Coffin 2003). It is also noteworthy that the participants in this study, as female and male EFL professionals in Saudi Arabia, although they had different linguistic and cultural backgrounds and orientations to instructional practice, shared concerns regarding time, class sizes, and heavy work-load as well as meeting curriculum deadlines set by their institutions when it came to their perspective of WCF practices. However, more often than not, the teacher's thinking is invisible unless expressly articulated and brought into the big picture through research. One important finding in this study, which is directly related to question 1 in this study, is that the majority of the participating teachers (mainly in the interviews) saw WCF as something vital and important in SLA. This is in line with the proponents of the Noticing Hypothesis (Schmidt 1990), who advocate for the importance and benefits of WCF where the latter stimulates noticing and in drawing learners' attention to form (Robinson 1995; Rod 1994). With regards to questions 2 and 3 of this research study, the participants, in both the survey and interviews, expressed their desire to see tertiary institutions allocate designated classes for writing to help maximize the potential of their students and give them more confidence as well as reducing the pressure to use another skill (e.g., reading or listening) because the whole lesson is dedicated to writing. Pedagogically, the participants in the survey (open-ended question) as well as in the interviews made several suggestions for better practice in the classroom, which included helping the students get editing practice and become self-aware of their errors. It was suggested by one of the participants in one of the interviews that learners keep a journal with error codes that the teacher introduces to them at the beginning of the semester and in the next column (next to the error codes column), the frequency corresponding to the different errors that the students made.

\subsection{Recommendations for future research}

Future study should involve more teachers in different regional contexts, with different age groups, and using different teaching approaches to identify more WCF goals that teachers may intend to achieve. Because of the availability of participating teachers, the number of questions in the semi-structured interviews were different and I suggest that the number of questions should be standardized in any related future research.

\section{References}

Al-Shammari, H. (2005). An evaluation of the English textbook series (Say It in English) for the first and second intermediate grades from teachers' perspectives in Hai'l city in the Kingdom of Saudi Arabia. The University of Jordan. Amman, Jordan, University of Jordan.

Amrhein, H. R., \& Nassaji, H. (2010). Written corrective feedback: What do students and teachers think is right and why? Canadian Journal of Applied Linguistics, 13, 95-127.

Bailey, K. M. (2001). Action research, teacher research, and classroom research in language teaching. In Marianne Celce-Murcia. (Ed.), Teaching English as a second or foreign language (pp. 489-498). Boston, MA: Heinle \& Heinle.

Bitchener, J. (2008). Evidence in support of written corrective feedback. Journal of Second Language Writing, 17, (2): 102-118.

Bitchener, J., \& Knoch, U. (2008). The value of written corrective feedback for migrant and international students. Language Teaching Research, 12, (3): 409-431.

Bitchener, J., Young, S., Cameron, D. (2005). The effect of different types of corrective feedback on ESL student writing. Journal of Second Language Writing, 14, (3): 191-205.

Chandler, J. (2003). The efficacy of various kinds of error feedback for improvement in the accuracy and fluency of L2 student writing. Journal of Second Language Writing, 12, (3): 267-296.

Coffin, C. (2003). Teaching academic writing: A toolkit for higher education. London: Routledge.

Cohen, L., Manion, L., \& Morrison, K. (2007). Research methods in education. London, Routledge. 
Creswell, J. W. (2002). Educational research: planning, conducting, and evaluating quantitative and qualitative research. Upper Saddle River, NJ: Merrill/Prentice Hall.

Creswell, J. W. (2003). Research design: Qualitative, quantitative, and mixed methods approaches. Thousand Oaks, CA: Sage Publications.

Creswell, J.W. (2007). Qualitative inquiry \& research design (2nd ed.). Sage Publications: Thousand Oaks, CA.

Creswell, J. W., \& Clark, V. L. P. (2010). Designing and conducting mixed methods research. Thousand Oaks, CA: Sage Publications.

Erickson, F. (1986). Qualitative methods in research on teaching. In M. C. Wittrock

(Ed.), Handbook of research on teaching. New York: Macmillan.

Ferris, D. (1997). The influence of teacher commentary on student revision. TESOL Quarterly, 31, (2): 315-339.

Ferris, D. (1999). The case for grammar correction in L2 writing classes: A response to Truscott (1996). Journal of Second Language Writing, 8, (1): 1-11.

Ferris, D. (2002). Treatment of error in second language student writing. The University of Michigan Press, Michigan, USA.

Ferris, D. (2003). Response to student writing; Implications for second language students.

Mahwah, New Jersey: Lawrence Erlbaum Associates, Inc.

Ferris, D. (2004). The "grammar correction" debate in L2 writing: Where are we, and where do we go from here? (and what do we do in the meantime ...?). Journal of Second Language Writing, 13, (1): 49-62.

Ferris, D. (2006). Feedback in second language writing. Cambridge, MA: Cambridge University Press.

Ferris, D. (2007). Preparing teachers to respond to student writing. Journal of Second Language Writing, 16, (3): 165193.

Ferris, D. R., \& Helt, M (2000). Was Truscott right? New evidence on the effects of error correction in L2 writing classes. The American Association of Applied Linguistics Conference, Vancouver, B.C, Canada.

Ferris, D., \& Roberts, B. (2001). Error feedback in L2 writing classes: How explicit does it need to be? Journal of Second Language Writing, 10, (3): 161-184.

Gunderson, L. (2009). ESL (ELL) literacy instruction: a guidebook to theory and practice. London: Routledge.

Hairston, Maxine. "On Not Being a Composition Slave.” Training the New Teacher of Composition. Ed. Charles W. Bridges. Urbana: NCTE, 1986. Print. 117-124.

Holtgraves, T. (1999). Comprehending indirect replies: when and how are their conveyed meanings activated? Journal of Memory and Language, 41, (4): 519-540.

Hong, Y.(2004). The effect of teachers' error feedback on international students' self correction ability, Published Master's Thesis. Brigham Young University, Utah, The USA. Hopkins, D., \& Ahtaridou, E. (2008). A teacher's guide to classroom research. New York, NY: McGraw-Hill.

Hyland, F., \& Hyland, K. (2001). Sugaring the pill: Praise and criticism in written feedback. Journal of Second Language Writing, 10, (3): 185-212.

Kemper, E., Stringfield. S., \& Teddlie, C. (2003). Mixed methods sampling strategies in social science research. In Tashakkori, A., \& Teddlie, C. (Eds.), Handbook of Mixed Methods in Social and Behavioural Research (pp. 273-278). Thousand Oaks, CA: Sage Publications.

Kepner, C. G. (1991). An experiment in the relationship of types of written feedback to the development of secondlanguage writing skills. The Modern Language Journal, 75, (3): 305-313.

Lacorte, M., \& Krastel, T. C. (2002). ¿Zapatero a tus zapatos? Action research in the Spanish language classroom. Hispania, 85, (4): 907-917.

Lalande, J. F. (1984). Reducing composition errors: An experiment. Foreign Language Annals, 17, (2): $109-118$.

Lee, I. (2008). Student reactions to teacher feedback in two Hong Kong secondary classrooms. Journal of Second Language Writing, 17, (3): 144-164.

Mackey, A., \& Gass, S. M. (2005). Second language research: Methodology and design. London: Routledge.

Matsuda, P. K., Cox, M., Jordan, J., \& Ortmeier-Hooper, C. (2010). Second-language writing in the composition classroom: A critical sourcebook. London: Bedford/St. Martin's.

Montgomery, J. L., \& Baker, W. (2007). Teacher-written feedback: Student perceptions, teacher self-assessment, and actual teacher performance. Journal of Second Language Writing, 16, (2): 82-99.

Robinson, P. (1995). Attention, memory, and the "noticing" hypothesis. Language Learning, 45, (2): $283-331$.

Rod, E. (1994). The study of second language acquisition. Oxford, UK: Oxford University Press.

Semke, H. (1984). The effects of the red pen. Foreign Language Annals, 17, (3): 195-202. 
Sheppard, K. (1992). Two feedback types: Do they make a difference? RELC Journal, 23, (1): 103-110.

Schmidt, R. (1990). The role of consciousness in second language learning. Applied Linguistics,

11, 206-226.

Squires, D. \& Bliss, T. (2004). Teacher visions: Navigating beliefs about literacy learning. The Reading Teacher, 57, (8): $756-763$.

Thonus, T. (2002). Tutor and student assessments of academic writing tutorials: What is "success"? Assessing Writing, 8, (2): 110-134.

Truscott, J. (1996). The case against grammar correction in L2 writing classes. Language Learning, 46, (2): 327-369.

Truscott, J. (1999). The case for "The Case Against Grammar Correction in L2 Writing Classes": A response to Ferris. Journal of Second Language Writing, 8, (2): 111-122.

Ur, P. (1996). A course in language teaching: Practice and theory. Cambridge, MA: Cambridge University Press, UK.

Vyatkina, N. (2010). The effectiveness of written corrective feedback in teaching beginning German. Foreign Language Annals, 43, (4): 671-689.

Wallace, M. J. (1991). Training foreign language teachers: A reflective approach. Cambridge, England: Cambridge University Press.

Wayne, E.A. (2013). Written corrective feedback: the parameters and the opinions.

Humanising Language Teaching Online Magazine, Year 15; Issue 1; February 2013 http://www.hltmag.co.uk/feb13/mart03.htm, accessed 10 ${ }^{\text {th }}$ April, 2013.

\section{Appendix A}

The purpose of this research project is to explore EFL Teachers' Perception of Written corrective feedback. This is a research project being conducted by Lecturer **********. You are invited to participate in this research project because you are an EFL teacher at a University/College.

Your participation in this research study is voluntary. You may choose not to participate. If you decide to participate in this research survey, you may withdraw at any time. If you decide not to participate in this study or if you withdraw from participating at any time, you will not be penalized.

The procedure involves filling an online survey that will take a maximum of 5 minutes. Your responses will be confidential and we do NOT ask you for identifying information such as your name, email address, place of work or IP address. All data is stored in a password protected electronic format. To help protect your confidentiality, the survey will NOT contain information that will personally identify you. The results of this study will be used for scholarly purposes only. If you have any questions about the research study, please contact $* * * * *$ on $* * * * * * * * * *$

ELECTRONIC CONSENT: Please select your choice below.

Clicking on the "agree" button below indicates that:

- you have read the above information

- you voluntarily agree to participate

- you are at least 18 years of age

If you do not wish to participate in the research study, please decline participation by clicking on the "disagree" button.

Thank You.

$\begin{array}{ll}\circ & \text { Agree } \\ \circ & \text { Disagree }\end{array}$


2. What is your gender?

c

Female

(9) Male

3. What is the highest level of education you have completed?

C Diploma

Bachelor's Degree

Post Graduate Certificate of Education

C Master's Degree

$B$ Doctoral Degree

4. What course do you teach at your institution?

C PYP 1st Semester

$G$ PYP 2nd Semester

C PYP Other

C 101

C. 102

Other (please specify)

5. On average, how many students do you teach per class?
C $0-10$
G $11-15$
C $15-20$
C $21-25$
C $26-30$
C $>30$

6. How many contact hours do you have per day?
C 2 Hours
C 3 Hours
C 4 Hours
C 5 Hours
6 Hours
G $>6$ hours

7. At your institution, as part of the curriculum for EFL, is "writing" designated special classes?
Sis
Yes
S No

8. On average, how many written assignments do you require your students to complete per week?

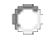
Once a week

C Twice a week

C Three times a week

C More than three times a week 
9. Generally speaking, do you provide your students with some sort of feedback on their written assignments?
G Yes
$B$ No

10. What is the percentage of the students' submitted written assignments that get written corrective feedback?
C $0-20 \%$
C $20-40 \%$
C $40-60 \%$
C60-80\%
C $80-100 \%$

11. On average, how many hours a week do you allocate for written corrective feedback?
C 1 - 2 Hours
C 2 - 3 Hours
C 3 - 4 Hours
G $>4$ hours

12. What type of written corrective feedback do you usually provide?
G
Unfocussed (comprehensive) direct feedback where all the errors are corrected.
G
$G$ Indirect Coded feedback where errors are indicated with particular codes
(sp. - spelling, prep.- preposition)...etc.
Indirect non-coded feedback where errors are merely indicated to the students

13. Do you generally provide your students with a follow up session after giving written corrective feedback on their assignments previously?

$\Leftrightarrow$ Yes

14. Do you believe that TIME is a crucial factor in your decision to follow a particular strategy in written corrective feedback? (e.g. Extensive feedback is given if ample time is allocated for writing practice and revision and/or small class size vs. selective coded feedback is given when short time is allocated for writing practice and revision and/or big class size).

$\begin{array}{cc}G & \text { Yes } \\ G & \text { No }\end{array}$

15. Please leave any additional comments you might have regarding teachers' perception of written corrective feedback below. 
Appendix B

Q1. What has been you experience so far in Saudi Arabia on the writing part of your EFL teaching?

Q2. How do you perform WCF on written assignments by your students?

Q3. Do you think there are issues related to WCF? For example, time, student proficiency, number of students in the class?

Q4. Tell me about what is "good WCF" in your opinion.

Q5. Give me a little bit more detail about the WCF practised in EFL at your institute.

\section{Appendix C}

\section{Consent Form}

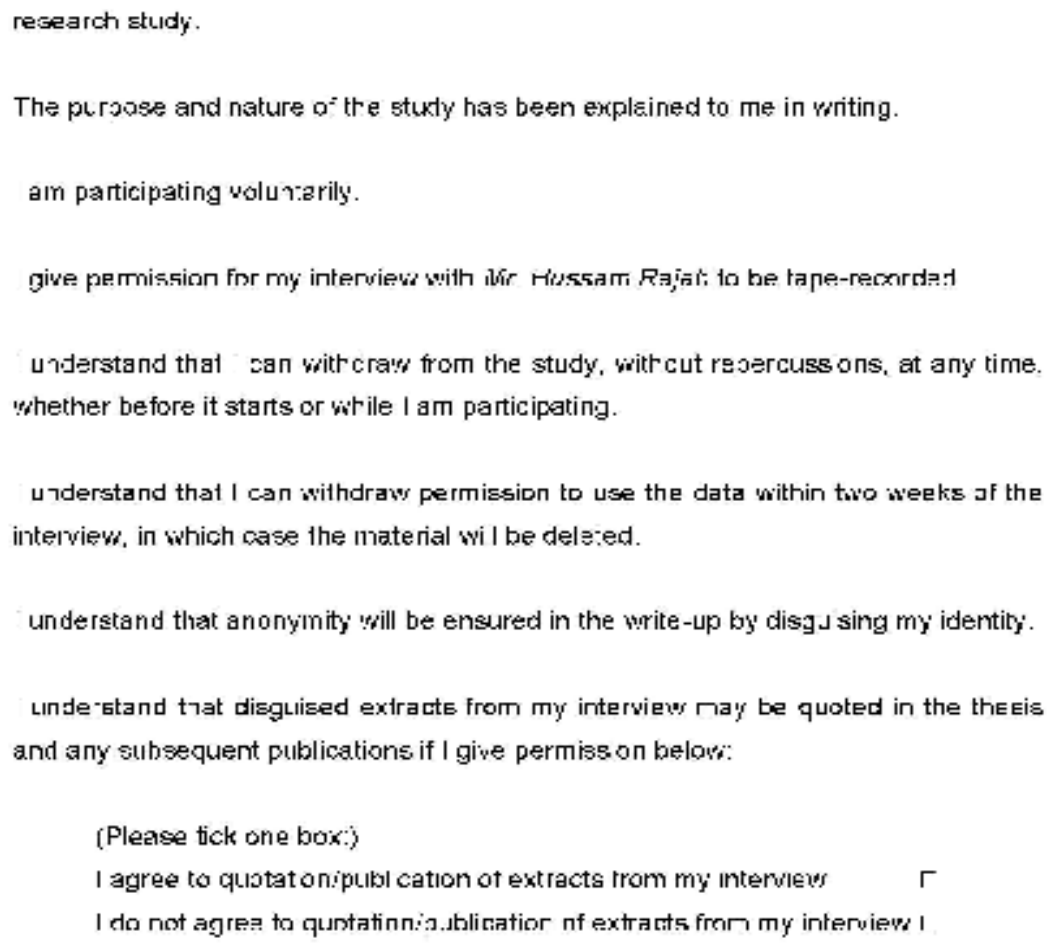

